\title{
DNA/HSA Interactions and Anticancer Activity of a Palladium(II) Saccharinate Complex Bearing Ethyldiphenylphosphine
}

\section{Etildifenilfosfin İçeren Bir Paladyum(II) Sakkarinat Kompleksinin DNA/HSA ile Etkileşimleri ve Antikanser Aktivitesi}

Ceyda İçel $^{\odot}$

Department of Chemistry, Uludag University, Bursa, Turkey.

\section{ABSTRACT}

The binding interactions of cis-[Pd(sac $\left.)_{2}\left(\mathrm{PPh}_{2} \mathrm{Et}\right)_{2}\right]$ with DNA and HSA were comprehensively studied by a number of experimental methods and molecular docking studies. The Pd(II) complex bound to AT-rich sites in the major groove of DNA, and interacted with the hydrophobic cavity of the subdomain IIA of HSA. These experimental findings were supported by molecular docking studies. The Pd(II) complex had shown strong cytotoxic activity against different cancer cell lines and it also had selectivity especially for MCF-7 breast cancer cells higher than cisplatin.

\section{Key Words}

Palladium(II), saccharinate, anticancer activity, DNA/HSA binding.

\section{ÖZ}

is- $\left[\mathrm{Pd}(\mathrm{sac})_{2}\left(\mathrm{PPh}_{2} \mathrm{Et}\right)_{2}\right]$ kompleksinin DNA ve HSA bağlanma etkileşimleri bir seri deneysel yöntem ve moleküler doking ile kapsamlı bir şekilde çalışıldı. Pd(II) kompleksi DNA'nın majör oluğundaki AT'ce zengin konumlara bağlandı ve HSA'nın IIA alt bölgesindeki hidrofobik boşluk ile etkileşti. Bu deneysel bulgular moleküler doking çalışmaları ile desteklendi. Pd(II) kompleksi farklı kanser türlerine karşı güçlü sitotoksik aktivite gösterdi. Özellikle MCF-7 meme kanser hücreleri için sisplatinden daha yüksek seçiciliğe sahip oldu.

\section{Anahtar Kelimeler}

Paladyum(II), sakkarinat, antikanser aktivite, DNA/HSA bağlanma.

Article History: Received: Dec 6, 2020; Revised: Dec 18, 2020; Accepted: Dec 22, 2020; Available Online: Dec 20, 2020.

DOI: https://doi.org/10.15671/hjbc.836685

Correspondence to: $\mathrm{C}$. İçsel, Department of Chemistry, Uludag University, Bursa, Turkey.

E-Mail: cydicsel@uludag.edu.tr 


\section{INTRODUCTION}

Biological activities of $\mathrm{Pd}(\mathrm{II})$ complexes received less attention compared to those of $\mathrm{Pt}$ (II) complexes, owing to use of cisplatin, $\left[\mathrm{PtCl}_{2}\left(\mathrm{NH}_{3}\right)_{2}\right.$, in the treatment of various types of cancer. However, the similarity between the coordination chemistry of $\mathrm{Pd}(\mathrm{II})$ and $\mathrm{Pt}(\mathrm{II})$ encouraged studies on biological activities of Pd(II) complexes. Studies in this field were well documented in the recent reviews [1-4], indicating that $\mathrm{Pd}(\mathrm{II})$ complexes may be considered as promising antiviral, antifungal, antimicrobial and antitumor agents.

Saccharin (sacH, 1,1-dioxo-1,2-benzothiazol-3-one or o-benzosulfimide) is well-known non-caloric synthetic sweetener and loses the imine proton in the aqueous solution to form the saccharinate anion (sac). The anion has several coordination sites such as imino nitrogen, carbonyl and sulfonyl groups towards metal ions and undergoes complexation rather easily with a wide range of metal ions [5]. Mixed-ligand $\mathrm{Pd}(\mathrm{II})$ and $\mathrm{Pt}(\mathrm{II})$ sac complexes displayed significant anticancer activity [6-11]. Our research group has recently synthesized a number of $\mathrm{Pd}(\mathrm{II})$ and $\mathrm{Pt}(\mathrm{II})$ sac complexes containing mono and diphosphines. The new complexes were tested for their anticancer activity and the results showed that the $\mathrm{Pt}(\mathrm{II})$ complexes displayed great cytotoxicity on various cancer cell lines [12-18]. During these studies, one Pd(II) complex cis-[Pd(sac) $\left.{ }_{2}\left(\mathrm{PPh}_{2} \mathrm{Et}\right)_{2}\right]$ (Figure 1) was found to exhibit cytotoxic activity on cancer cells and this paper presents the biological activity data of the complex. In addition, its interactions with important biological molecules such as DNA and human serum albumin (HSA) were studied using experimental methods and molecular docking calculations.

\section{MATERIALS and METHODS}

\section{Materials and Measurements}

The synthesis, characterization and X-ray structure of cis-[Pd(sac $\left.)_{2}\left(\mathrm{PPh}_{2} \mathrm{Et}\right)_{2}\right]$ was reported earlier [19]. All chemicals were purchased and used without further purification. UV-vis spectra were measured on a Perkin Elmer Lambda 35 spectrophotometer, while fluorescence spectra were recorded at room temperature with a Varian Cary Eclipse spectrophotometer equipped with a Xe pulse lamp of $75 \mathrm{~kW}$.

\section{DNA/HSA Binding Studies}

In DNA binding experiments, fish sperm (FS) DNA was used. A stock solution of FS-DNA was prepared in the Tris- $\mathrm{HCl}$ buffer (20 mM Tris- $\mathrm{HCl} / \mathrm{NaCl}, \mathrm{pH}=7.0$ ), while a stock solution of cis-[Pd(sac) $\left.{ }_{2}\left(\mathrm{PPh}_{2} \mathrm{Et}\right)_{2}\right]$ was prepared in $\mathrm{MeOH}$. The UV-vis spectra of the FS-DNA solution (50 $\mu \mathrm{M})$ treated with increasing the concentration of the $\mathrm{Pd}(\mathrm{II})$ complex $(0-50 \mu \mathrm{M})$ were recorded and the intrin-

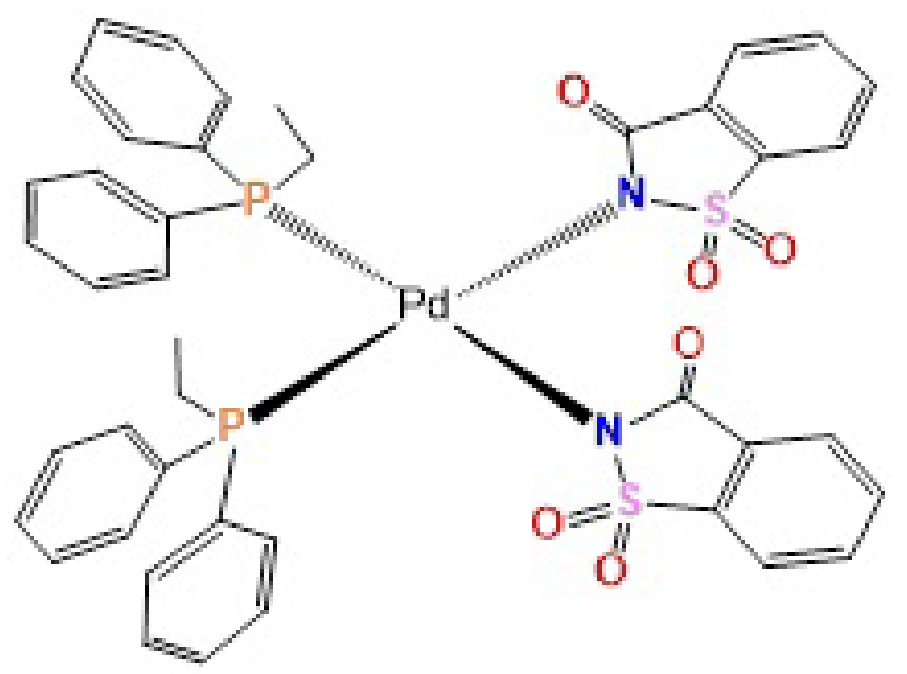

Figure 1. Molecular structure of cis-[ $\left.\mathrm{Pd}(\mathrm{Sac})_{2}\left(\mathrm{PPh}_{2} \mathrm{Et}\right)_{2}\right]$. 
sic binding constant $\left(K_{\mathrm{b}}\right)$ was calculated according to the Benesi-Hildebrand equation [20]. In fluorescence measurements, the $\mathrm{Pd}(\mathrm{II})$ complex $(0-50 \mu \mathrm{M})$ was added to FS-DNA solution $(50 \mu \mathrm{M})$ pre-treated with ethidium bromide (EB) $(5 \mu \mathrm{M})$ in Tris- $\mathrm{HCl}$. The emission spectra of these solutions were recorded upon excitation at $\lambda_{\text {ex }}$ $=295 \mathrm{~nm}$. The quenching constant $\left(K_{\mathrm{sV}}\right)$ was determined using the Stern-Volmer equation [21], while the binding constant $K_{\mathrm{F}}$ was determined from the Scatchard equation [22]. The viscosity of the FS-DNA solutions ( $25 \mu \mathrm{M})$ mixed with increasing amounts of the $\mathrm{Pd}(\mathrm{II})$ complex $(0-2 \mu \mathrm{M})$ was measured using an Ubbelohde viscometer at $20{ }^{\circ} \mathrm{C}$. Viscosity values were calculated from the observed flow time of DNA-containing solutions $(t)$ corrected for the flow time of buffer alone $\left(t_{0}\right), \eta=t-$ $t_{0}$. The melting of DNA was determined by the UV/Vis spectrophotometer equipped with a Peltier temperature programmer. The temperature of the FS-DNA solutions $(100 \mu \mathrm{M})$ containing the $\mathrm{Pd}(\mathrm{II})$ complex $(25 \mu \mathrm{M})$ was monitored from 25 to $95{ }^{\circ} \mathrm{C}$. The melting temperature $\left(T_{m}\right)$ were determined from the plot of relative absorbance $\left(\mathrm{A} / \mathrm{A}_{25}\right)$ at $260 \mathrm{~nm}$ versus temperature.

A stock solution of HSA was prepared in Tris-HCl buffer ( $5 \mathrm{mM}$ Tris- $\mathrm{HCl}, 10 \mathrm{mM} \mathrm{NaCl}, \mathrm{pH}=7.4$ ). UV-vis spectra of the HSA solutions $(10 \mu \mathrm{M})$ containing the $\mathrm{Pd}(\mathrm{II})$ complex $(0-20 \mu \mathrm{M})$ were performed and the binding constant $\left(K_{\mathrm{b}}\right)$ was calculated using the Benesi-Hildebrand equation [20]. Fluorescence titration experiments were carried out at a constant concentration of HSA (5 $\mu \mathrm{M})$ and varying concentrations of the $\mathrm{Pd}(\mathrm{II})$ complex (0-10 $\mu \mathrm{M})$ upon excitation at $280 \mathrm{~nm}$. The binding constant $\left(K_{F}\right)$ was obtained from the Scatchard equation [22]. Synchronous fluorescence spectra were measured at two different $\Delta \lambda$ values (difference between the $\lambda_{\text {ex }}$ and $\lambda_{\text {em }}$ ), setting $\Delta \lambda=15 \mathrm{~nm}$ and $\Delta \lambda=60 \mathrm{~nm}$ for Tyr and Trp, respectively.

\section{Gel Electrophoresis Studies}

The solutions containing $20 \mu \mathrm{g}$ plasmid DNA and the $\mathrm{Pd}(\mathrm{II})$ complex $(0-250 \mu \mathrm{M})$ in $50 \mathrm{mM}$ Tris- $\mathrm{HCl} / \mathrm{NaCl}$ buffer ( $\mathrm{pH}$ 7.2) were incubated at $37^{\circ} \mathrm{C}$ for $4 \mathrm{~h}$. In a separate experiment, the plasmid DNA was incubated with MG and DAPI $(100 \mu \mathrm{M})$ for $1 \mathrm{~h}$ and then the Pd(II) complex $(100 \mu \mathrm{M})$ was added to the solution. The final solutions were incubated another $3 \mathrm{~h}$. The samples were electrophoresed for $45 \mathrm{~min}$ at $120 \mathrm{~V}$ on $1.0 \%$ agarose gel using $1 X$ TBE buffer ( $\mathrm{pH}$ 8.0). In restriction enzyme inhibition studies, the plasmid DNA was incubated with 50 $\mu \mathrm{M}$ of the complexes at $37^{\circ} \mathrm{C}$ in the buffer $(\mathrm{pH}$ 7.2) for $1 \mathrm{~h}$. These solutions were subsequently incubated separately with HindIII and BamHI (2 units) for $15 \mathrm{~min}$. The results of incubation were obtained from $1.5 \%(\mathrm{w} / \mathrm{v})$ agarose gel electrophoresis in $1 \mathrm{X}$ TBE buffer. The gels were then stained using $1 \mu \mathrm{g} \mathrm{cm}^{-3} \mathrm{~EB}$ and photographed under UV light.

\section{Molecular Docking Studies}

Molecular docking studies were carried out using Autodock/Vina [23]. The crystal structures of 1BNA (CGCGAATTCGCG) and $1 \mathrm{H} 9 \mathrm{Z}$ (HSA) were taken from the Protein Data Bank. The binding site was centered on the DNA or HSA and a grid box was created with $60 \times 60 \times 60$ points and a $0.375 \AA$ grid spacing in which almost the entire macromolecules were involved. For each docking calculation, 10 different poses were required within the energy range of $2 \mathrm{kcal} \mathrm{mol}^{-1}$. All other parameters were kept at their default values. The docked molecules were visualized by Discovery Studio 3.5 software.

\section{Cell Viability Assay}

Lung cancer (A549), breast cancer (MCF-7), colon cancer (HCT116) and human bronchial epithelial cells (BEAS-2B) were cultured with RPMI 1640 culture media supplemented with penicillin $\mathrm{G}(100 \mathrm{U} / \mathrm{mL})$, streptomycin $(100 \mu \mathrm{g} / \mathrm{mL})$, L-glutamine, and $10 \%$ fetal bovine serum at $37{ }^{\circ} \mathrm{C}$ in a humidified atmosphere containing $5 \% \mathrm{CO}_{2}$. The $\mathrm{Pd}(\mathrm{II})$ complex was dissolved in DMSO and further dilutions were prepared in cell culture medium. Final concentration of DMSO was maximum $0.1 \%$ in order to avoid its toxic effect on cells. The cell viability was determined using the ATP viability method, which based on the measurement of intracellular ATP content in cells. A549, MCF-7, HCT116 and BEAS-2B cells were seeded $5 \times 10^{3}$ cells /well and treated for $48 \mathrm{~h}$ with the $\mathrm{Pd}(\mathrm{II})$ complex. Cisplatin was used as a positive control. The ATP content in the treated cells and control cells was measured using a luminometer (Lumistar Omega microplate reader, Germany) according to the principle of luciferin-luciferase bioluminescence reaction. Measuring time was 1 second. Results were obtained as Relative Light Unit (RLU) and the \% viability of the samples was calculated according to the RLU values obtained from the control cells. Viability was calculated by using the formula below:

Viability $(\%)=[100 \times($ Sample RLU) $/($ Control RLU) $]$ 


\section{RESULTS and DISCUSSION}

\section{Interaction with DNA}

Interaction of cis-[Pd(sac) $\left.)_{2}\left(\mathrm{PPh}_{2} \mathrm{Et}\right)_{2}\right]$ with FS-DNA was investigated a number of experimental methods. Firstly, electronic absorption spectroscopy was used to detect interactions between biomolecules and metal complexes. As shown in Figure 2a, the addition of the $\mathrm{Pd}(\mathrm{II})$ complex results in a increase in absorption intensity of the UV band of the FS-DNA solutions with a $5 \mathrm{~nm}$ redshift, which implies that there exists an interaction between the Pd(II) complex and DNA. The binding constant $\left(K_{\mathrm{b}}\right)$ obtained from the spectral data (Table 1 ) compares well with the corresponding $\mathrm{Pt}(\mathrm{II})$ sac complexes with monophosphines $[12,17]$, and indicates that the $\mathrm{Pd}(\mathrm{II})$ complex successfully binds to DNA.
EB fluorescence displacement experiments were used to investigate the DNA binding of the $\mathrm{Pd}(\mathrm{II})$ complex. The intrinsic fluorescence intensity of both DNA and $E B$ is low in the Tris buffer. However, after addition into DNA, the fluorescence intensity of EB is greatly enhanced due to intercalation between the base pairs of DNA. Thus, the exchange of EB can be used to probe the interaction of molecules with DNA. If the molecules intercalate into DNA or binding the grooves of DNA, the binding sites of DNA available for EB will be diminished, and consequently, the fluorescence intensity of EB will be quenched. The fluorescence intensity of FSDNA solutions pretreated with EB shows a remarkable decrease with an increase in the amount of the $\mathrm{Pd}(\mathrm{II})$ complex (Figure 2b). This observation clearly indicates that the $\mathrm{Pd}(\mathrm{II})$ complex interact with FS-DNA through (a)

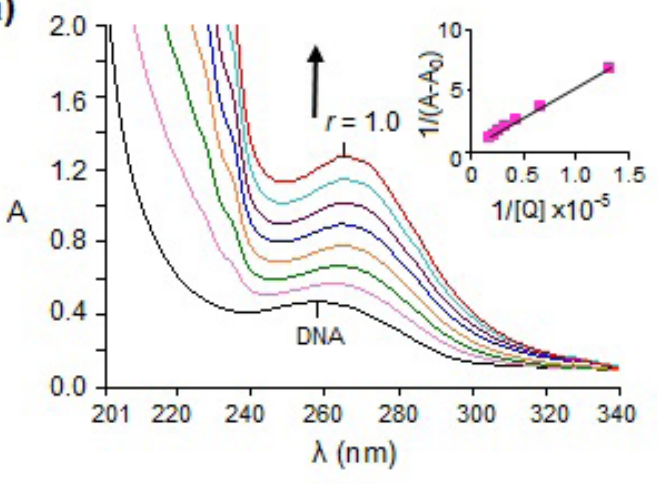

(c)

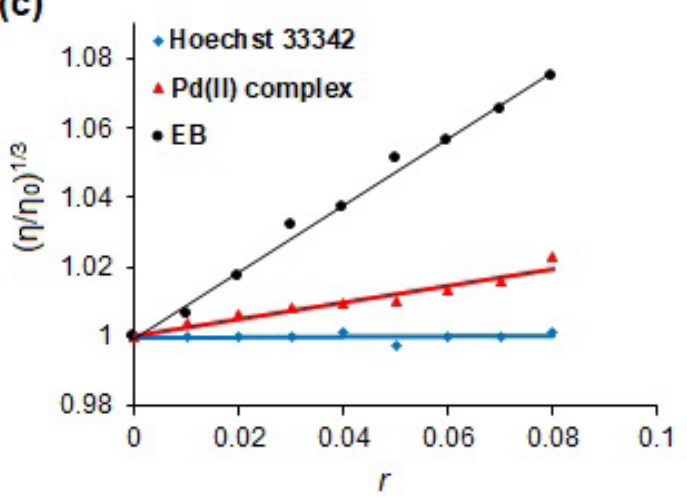

(b)

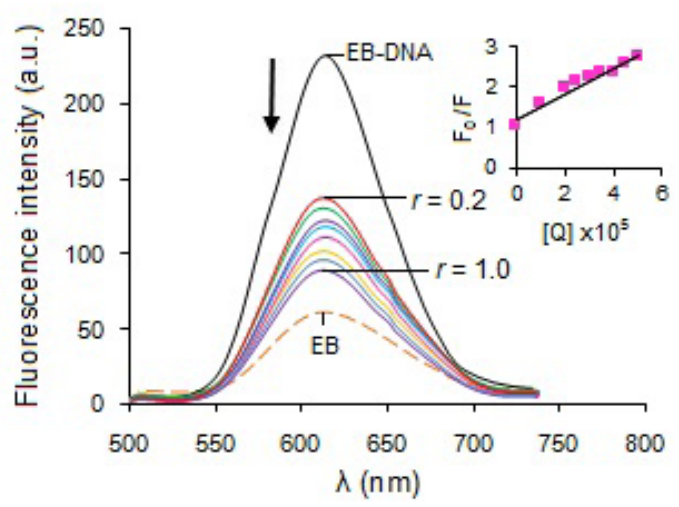

(d)

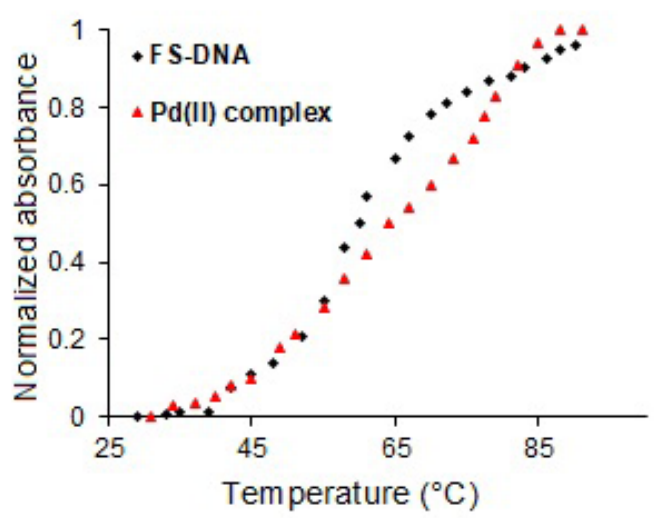

Figure 2. DNA binding data: (a) UV-vis spectra, (b) fluorescence emission spectra (EB-bound DNA) and (c) viscosity of the DNA solutions upon addition of increasing amounts of cis-[Pd(sac) $\left.)_{2}\left(P_{2} h_{2} E t\right)_{2}\right]$. (d) Melting of the DNA solutions (100 $\left.\mu M\right)$ containing the Pd(II) complex $(25 \mu \mathrm{M})$. Arrows show the changes in the spectral intensity with increasing concentrations of the Pd(II) complex. $r=[$ Complex]/[DNA(bp)]. Insets: plot of 1/[complex] vs. 1/(A-A0) for UV-Vis data and Stern-Volmer plot of the fluorescence data. 
Table 1. Binding parameters for the interaction of cis- $\left[\mathrm{Pd}(\mathrm{Sac})_{2}\left(\mathrm{PPh}_{2} \mathrm{Et}\right)_{2}\right]$ with DNA and HSA.

\begin{tabular}{cccc}
\hline \multicolumn{1}{c}{$\mathrm{K}_{\mathrm{b}}\left(\mathrm{M}^{-1}\right)$} & $\mathrm{K}_{\mathrm{SV}} \times\left(\mathrm{M}^{-1}\right)$ & $\mathrm{K}_{\mathrm{F}} \times\left(\mathrm{M}^{-1}\right)$ & $\mathrm{n}$ \\
\hline DNA binding & & & \\
\hline $0.53( \pm 0.03) \times 10^{4}$ & $1.13( \pm 0.05) \times 10^{4}$ & $1.47( \pm 0.05) \times 10^{4}$ & 1.0 \\
\hline HSA binding & & & 0.9 \\
\hline $0.57( \pm 0.04) \times 10^{4}$ & $2.16( \pm 0.07) \times 10^{4}$ & $7.95( \pm 0.12) \times 10^{5}$ & \\
\hline
\end{tabular}

the groove binding mode, releasing some EB molecules from EB-DNA system. The quenching of EB bound to DNA by the $\mathrm{Pd}(\mathrm{II})$ complex is in agreement with the linear Stern-Volmer and the Scatchard equations. The quenching $\left(K_{\mathrm{sv}}\right)$ and fluorescence binding constant $\left(K_{\mathrm{F}}\right)$ values given in Table 1 are similar to that obtained from UV spectral data. In addition, the $n$ value (number of binding sites) corresponds to a 1:1 molecular ratio between the $\mathrm{Pd}(\mathrm{II})$ complex and DNA nucleotides.

Spectroscopic methods are only indicative of binding of molecules to DNA, but they are not sufficient to suggest a binding mode. The viscosity of DNA solutions is susceptible to the binding mode of molecules. Intercalation of a molecule into DNA results in an increase in DNA viscosity, since base pairs are separated to accommodate the new molecule and hence the DNA helix lengthens. On the other hand, groove binding of a molecule does not affect the length of the DNA helix and also DNA viscosity. Therefore, the measurement of viscosity of DNA solutions is regarded as the most sensitive method to determine the binding mode of molecules [24]. The viscosity of FS-DNA solutions was measured in the presence of EB (a DNA intercalator), Hoechst 33342 (a DNA groove binder) and the $\mathrm{Pd}(\mathrm{II})$ complex (Figure 2c). The viscosity of FS-DNA solutions changes slightly in the presence of increasing amounts of the Pd(II) complex, suggesting that the complex interacts with DNA through groove binding.

When a DNA solution is heated, the induction of conformational changes occurs and the double strands is separated. The DNA denaturation is called as DNA melting. The melting point $\left(T_{\mathrm{m}}\right)$ of the DNA solutions is measured at $260 \mathrm{~nm}$ as a function of temperature (Figure $2 \mathrm{~d}$ ). The FS-DNA solution $(100 \mu \mathrm{M})$ has a melting point of $63^{\circ} \mathrm{C}$. At a complex/DNA ratio of 0.25 , the $\mathrm{Pd}(\mathrm{II})$ complex inc- reases in the melting point of DNA by ca. $4{ }^{\circ} \mathrm{C}$, indicating the increased stability of the DNA double helix in the presence of the $\mathrm{Pd}(\mathrm{II})$ complex, due to its strong interaction with DNA.

\section{DNA Cleavage}

Transition metal complexes may activate DNA cleavage reactions $[25,26]$. The different DNA nuclease activity of the metal complexes corresponds to their different binding affinity towards DNA. The gel electrophoretic separations showing the cleavage of pBR322 plasmid DNA induced by the Pd(II) complex were illustrated in Figure $3 a$. When a plasmid DNA is conducted by electrophoresis, the fastest migration is observed for the supercoiled form (SC). If one strand is cleaved, the supercoiled generates a slower-moving open circular form (OC). If both strands are cleaved, a linear form (L) forms and migrates in between. The $\mathrm{Pd}(\mathrm{II})$ complex converts the SC form of plasmid DNA to the OC form even at 10 $\mu \mathrm{M}$ in the absence of any internal agent. At higher concentrations over $50 \mu \mathrm{M}$, the OC form begins to diminish due to degradation of the OC form to smaller fragments of DNA. In agreement with the experimental observations given above, the present data suggest that the $\mathrm{Pd}(\mathrm{II})$ complex strongly binds to DNA.

The groove binding selectivity of the Pd(II) complex towards DNA was studied in the presence of a minor groove binder (DAPI, 4,6-diamidino-2-phenylindole) and a major groove binder (MG, methyl green). The groove binders display different DNA cleavage activity on the plasmid DNA incubated with the Pd(II) complex (Figure 3b). The $\mathrm{Pd}(\mathrm{II})$ complex shows nuclease activity in the 
presence of DAPI, whereas addition of MG completely inhibits the DNA cleavage activity of the Pd(II) complex, suggesting that the $\mathrm{Pd}(\mathrm{II})$ complex act as a DNA major groove binder, in agreement with the results obtained in the DNA binding studies. In addition, the binding specificity of the Pd(II) complex towards the base sequence of DNA was assessed by the enzyme inhibition assay

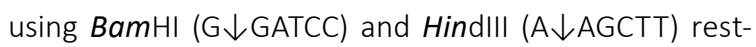
riction endonucleases possessing different recognition sites. As shown in Figure 3c, the Pd(II) complex is unable to inhibit BamHI and the most of the SC form of plasmid DNA is linearized by this enzyme. However, the endonuclease action of HindIII is completely inhibited by the $\mathrm{Pd}(\mathrm{II})$ complex. The present results suggest that the $\mathrm{Pd}(\mathrm{II})$ complex is a high affinity DNA major groove binder with a preference for Adenine (A)/Thymine ( $T$ )-sites of DNA. Similar results were observed Pt sac complexes of other tertiary phosphines $[12,17,18]$.

\section{Interaction with HSA}

As shown in Figure $4 a$, the addition of cis$\left[\mathrm{Pd}(\mathrm{sac})_{2}\left(\mathrm{PPh}_{2} \mathrm{Et}\right)_{2}\right]$ gradually increases the absorbance of the HSA solutions, indicating binding of the complex. The binding constant $\left(K_{b}\right)$ in Table 1 is similar to those reported for the corresponding Pt(II) complexes [12, 17], but somewhat lower than those of warfarin, and phenyIbutazone drugs bound to HSA with high affinity [27].

It is well established that, the intrinsic fluorescence of HSA is mainly due to the aromatic tryptophan (Trp), tyrosine (Tyr) and phenylalanine (Phe) residues in HSA. The fluorescence emission of the HSA solutions is quenched by the $\mathrm{Pd}(\mathrm{II})$ complex (Figure $4 \mathrm{~b}$ ). The corresponding binding constants $\left(K_{\mathrm{SV}}\right.$ and $\left.K_{\mathrm{F}}\right)$ given in Table 1 compare well with those of the $\mathrm{Pt}(\mathrm{II})$ sac complexes of monophoshines. Since the fluorescence emission peaks for the Tyr and Trp fluorophores are sensitive to the polarity of their environment, the change in the microenvironments of these residues is detected by the synchronous fluorescence measurements. The characteristic emissions for the Tyr and Trp residues of HSA are obtained by fixing the wavelength intervals $(\Delta \lambda)$ at 15 and $60 \mathrm{~nm}$, respectively [28]. Figures $4 \mathrm{c}$ and $4 \mathrm{~d}$ demonstrate that upon gradual addition of the $\mathrm{Pd}(\mathrm{II})$ complex, the maximum emission wavelength of the Tyr and Trp residues did not change significantly, although their fluorescence intensities decreased considerably. The present results indicate that the binding of the Pd(II) complex to HSA did not lead to a change in the polarity of the microenvironment of the Trp and Tyr residues. However, it causes changes in the internal packing of HSA [29].

\section{Molecular Docking}

The docking models of DNA (PDB ID: 1BNA) showed that cis-[Pd(sac) $\left.)_{2}\left(\mathrm{PPh}_{2} \mathrm{Et}\right)_{2}\right]$ binds to the $A$ rich sequence in the major groove of DNA (Figure $5 \mathrm{a}$ ) in agreement with observations obtained from the binding experiments of the complex. The $\mathrm{Pd}(\mathrm{II})$ complex forms strong $\mathrm{N}-\mathrm{H} \cdots \mathrm{O}$ hydrogen bonds with the A bases of DNA through the carbonyl and sulfonyl groups of the sac ligand in the complex (Table 2). The free binding energy of the docked molecule was computed as $-24.69 \mathrm{~kJ} \mathrm{~mol}^{-1}$, which is very close to that obtained from the fluorescence binding data $\left(-23.39 \mathrm{~kJ} \mathrm{~mol}^{-1}\right)$.

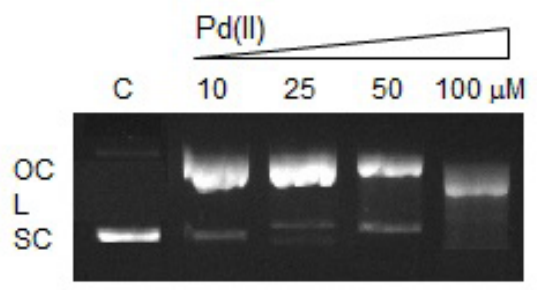

(a)

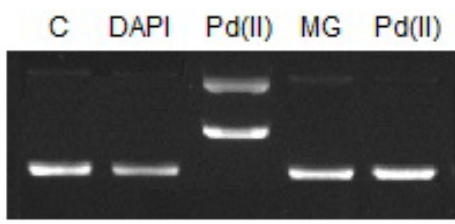

(b)

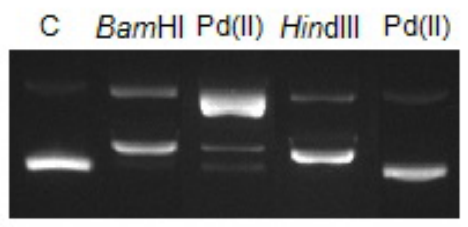

(c)

Figure 3. (a) Cleavage of pBR322 plasmid DNA $(20 \mu \mathrm{M})$ by cis- $\left[\mathrm{Pd}(\mathrm{sac})_{2}\left(\mathrm{PPh}_{2} \mathrm{Et}\right)_{2}\right]$ after incubation for $4 \mathrm{~h}$ at $37^{\circ} \mathrm{C}$, (b) Effect of groove binders DAPI and MG $(100 \mu \mathrm{M})$ on the cleavage of plasmid DNA in the absence and presence of the Pd(II) complex (100 $\mu \mathrm{M})$ and (c) Effect of the Pd(II) complex $(50 \mu \mathrm{M})$ on the cleavage of the plasmid DNA digested with BamHI and HindIII enzymes. C is the control. 
(a)

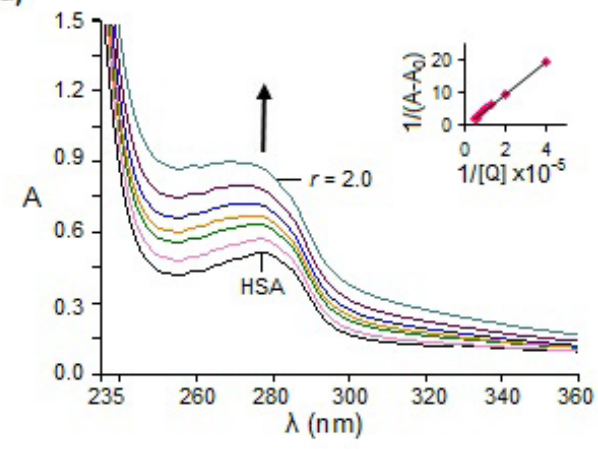

(c)

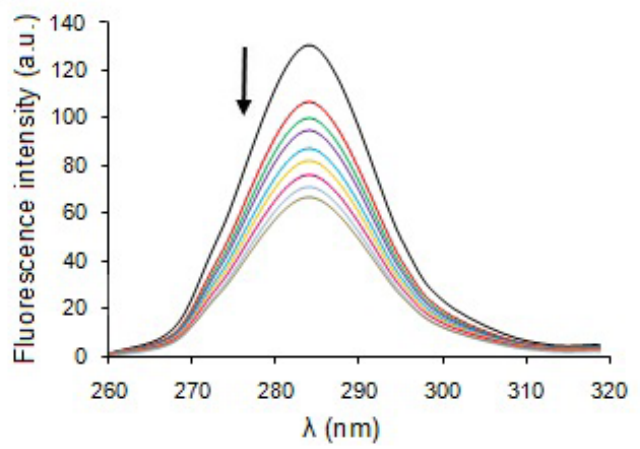

(b)

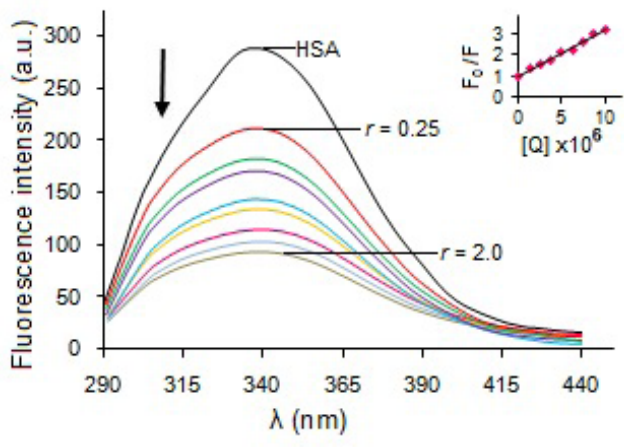

(d)

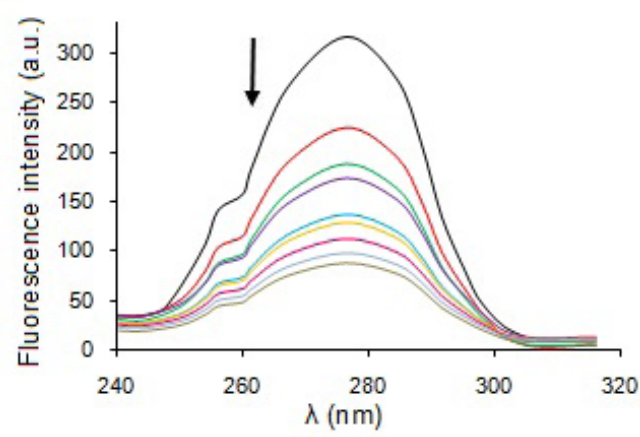

Figure 4. HSA binding data: (a) UV-vis spectra, (b) fluorescence emission spectra, (c) synchronous fluorescence spectra (at $\Delta \lambda=15$ $\mathrm{nm}$ ) and (d) synchronous fluorescence spectra (at $\Delta \lambda=60 \mathrm{~nm}$ ) of the HSA solutions upon addition of increasing amounts of cis$\left[\mathrm{Pd}(\mathrm{sac})_{2}\left(\mathrm{PPh}_{2} \mathrm{Et}\right)_{2}\right]$. Arrows show the changes in the spectral intensity with increasing concentrations of the Pd(II) complex. $r=[\mathrm{Comp}-$ lex]/[HSA]. Insets: plot of $1 /$ [complex] vs. 1/(A-AO) for UV-Vis data and Stern-Volmer plot of the fluorescence data.

Molecular docking of the Pd(II) complex with HSA (PDB ID: $1 \mathrm{H} 9 \mathrm{Z})$ displayed that the complex favourably entered the hydrophobic cavity of the subdomain IIA and was surrounded by 3 amino acid residues, such as Glu153, Lys-199 and His-242 via hydrophobic interactions (Figure $5 \mathrm{~b}$ and Table 2). The free binding energy of the docked structure was calculated as $-30.96 \mathrm{~kJ} \mathrm{~mol}^{-1}$, highly similar to the experimental data of fluorescence quenching $\left(-31.76 \mathrm{~kJ} \mathrm{~mol}^{-1}\right)$.

\section{Anticancer Activity}

The in vitro cytotoxic activity of cis-[Pd(sac) $\left.)_{2}\left(\mathrm{PPh}_{2} \mathrm{Et}\right)_{2}\right]$ was determined by the ATP assay against lung cancer (A549), breast cancer (MCF-7), colon cancer (HCT116) and human bronchial epithelial cells (BEAS-2B) and compared with the clinically used reference complex, cisplatin. The dose-response curves in Figure 6 indicated that the viability of the cells depends on the concentration the complex and the $\mathrm{IC}_{50}$ values (the concentration for $50 \%$ inhibition of cell viability) (Table 3 ) showed that the $\mathrm{Pd}(\mathrm{II})$ complex was significantly more potent against MCF-7 and HCT116 cancer cell lines, but it was practically inactive on A549 cells in the selected dose range. In addition the cytotoxic efficacy of the Pd(II) complex on MCF-7 cells was greater than that of cisplatin. Moreover, it is less toxic to normal cells (BEAS-2B) compared to cisplatin. The present results suggest that the $\mathrm{Pd}(\mathrm{II})$ complex displays selectivity for MCF-7 cell line. 


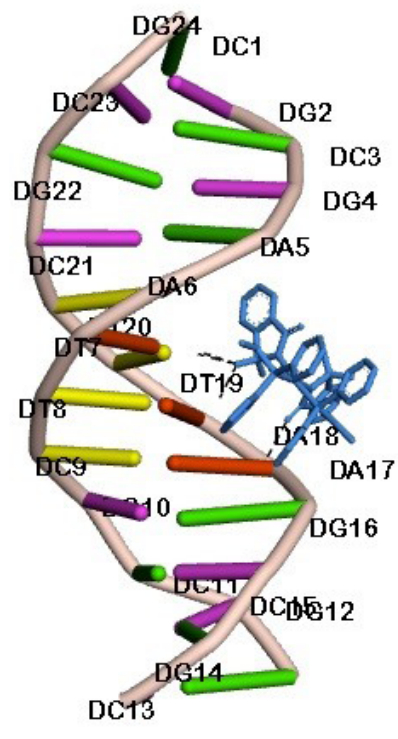

(a)

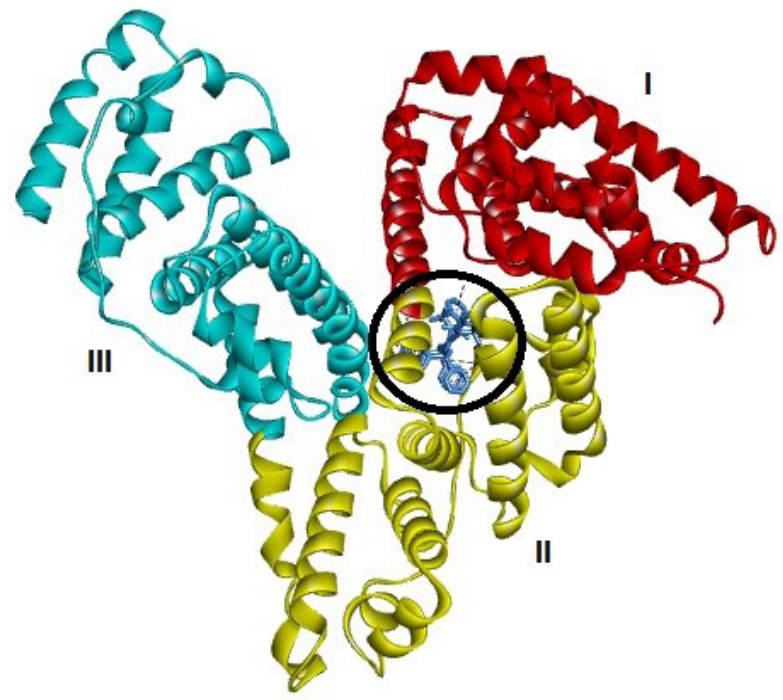

(b)

Figure 5. Molecular docking of cis-[Pd( $\left(\mathrm{Sac}_{2}\left(\mathrm{PPh}_{2} \mathrm{Et}\right)_{2}\right]$ with DNA (a) and HSA (b).

Table 2. Intermolecular interactions of cis-[Pd(sac) $\left.{ }_{2}\left(\mathrm{PPh}_{2} \mathrm{Et}\right)_{2}\right]$ with DNA and HSA.

\begin{tabular}{|c|c|c|c|c|}
\hline Hydrogen bonding & Distance $(\AA ̊)$ & $\begin{array}{l}\text { Hydrophobic } \\
\text { interaction }\end{array}$ & Distance $(\AA ̊)$ & $\Delta \mathrm{G}\left(\mathrm{kJ} \mathrm{mol}{ }^{-1}\right)$ \\
\hline \multicolumn{5}{|l|}{ DNA docking (1BNA) } \\
\hline DA18:H61‥O3(sulfonyl) & 2.42 & - & - & -24.69 \\
\hline 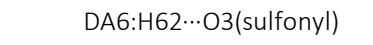 & 2.61 & - & - & \\
\hline 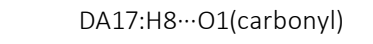 & 2.86 & - & - & \\
\hline DA6:H61‥03(sulfonyl & 2.94 & - & - & \\
\hline \multicolumn{5}{|l|}{ HSA docking (1H9Z) } \\
\hline 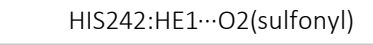 & 2.07 & 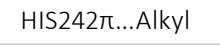 & 3.43 & -30.96 \\
\hline \multirow[t]{3}{*}{ 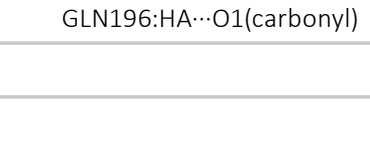 } & 2.27 & GLU153:OE2 ... & 3.72 & \\
\hline & & LYS199:CB... $\pi$ & 3.77 & \\
\hline & & HIS $242 \pi \ldots \pi$ & 4.40 & \\
\hline
\end{tabular}

Table 3. Cytotoxic activity (IC50, $\mu \mathrm{M})$ of cis-[Pd( $\left.(\mathrm{Sac})_{2}\left(\mathrm{PPh}_{2} \mathrm{Et}\right)_{2}\right]$.

\begin{tabular}{ccccc}
\hline & MCF-7 & A549 & HCT116 & BEAS-2B \\
\hline cis-[Pd(sac)2(PPh2Et)2] & $8.34 \pm 0.11$ & $>40$ & $26.15 \pm 0.59$ & $16.95 \pm 0.11$ \\
\hline Cisplatin & $13.89 \pm 0.14$ & $18.73 \pm 0.34$ & $15.53 \pm 1.60$ & $7.49 \pm 0.31$ \\
\hline
\end{tabular}



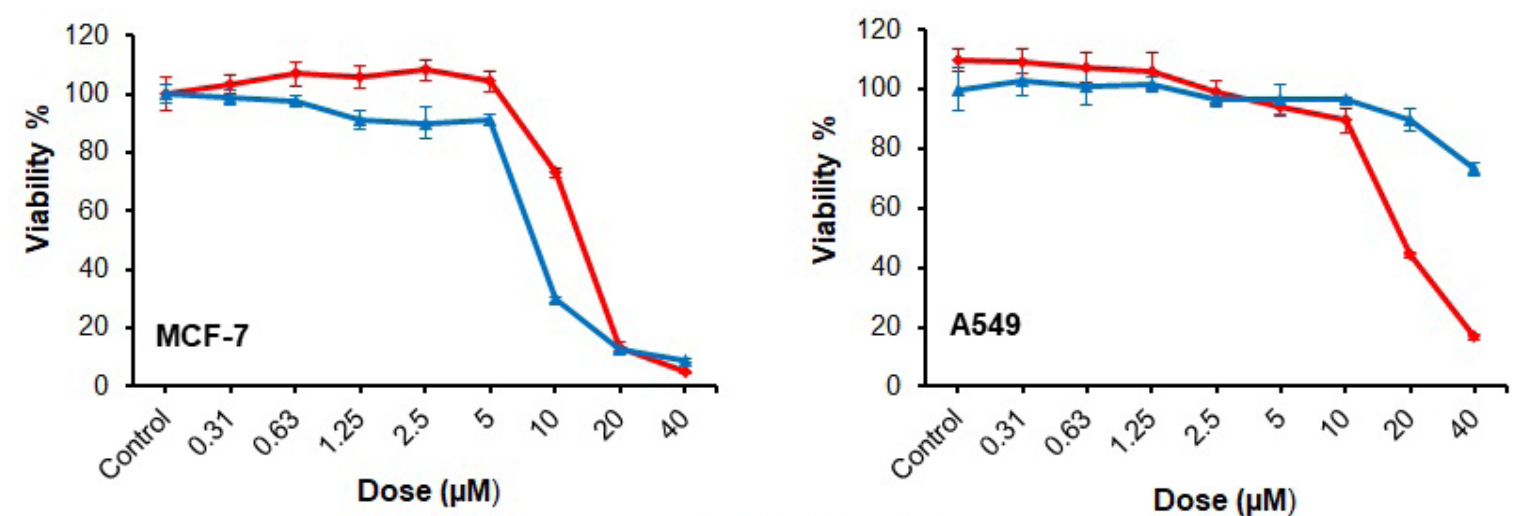

\section{$-\mathrm{Pd}(\mathrm{II})$ complex}

- cisplatin
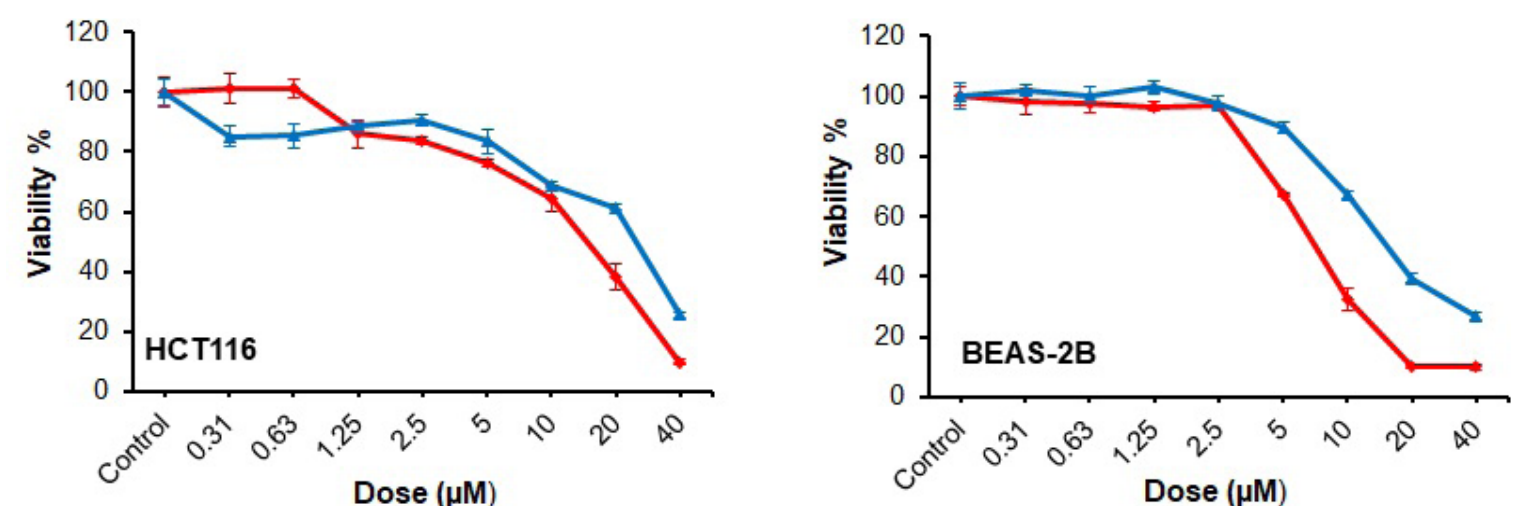

Figure 6. The dose-response graphics for cis- $\left[\mathrm{Pd}(\mathrm{sac})_{2}\left(\mathrm{PPh}_{2} \mathrm{Et}\right)_{2}\right]$ and cisplatin obtained from ATP assay, showing the effect of the complexes on the growth of the cell lines after $48 \mathrm{~h}$ of treatment.

\section{CONCLUSION}

In summary, cis-[Pd(sac) $\left.)_{2}\left(\mathrm{PPh}_{2} \mathrm{Et}\right)_{2}\right]$ efficiently binds to DNA and prefers AT-rich sites in the major groove binding mode. This complex also strongly interacts with HSA trough hydrophobic interactions. The experimental observations of binding studies were confirmed by molecular docking studies. The Pd(II) complex exhibits potent antitumor activity against human cancer cell lines of MCF-7 and HCT116 and displays higher anticancer activity and selectivity on MCF-7 cells as compared cisplatin.

\section{Acknowledgments}

The assistance of Dr. Buse Cevatemre (Koç Üniversity) in the cytotoxicity experiments is greatly acknowledged.

\section{Conflict of Interest}

Authors declare that they have no conflict of interest.

\section{References}

1. A. Garoufis, S.K. Hadjikakou, N. Hadjiliadis, Palladium coordination compounds as anti-viral, anti-fungal, antimicrobial and anti-tumor agents, Coord. Chem. Rev., 253 (2009) 1384-1397.

2. Md N. Alam, F. Huq, Comprehensive review on tumour active palladium compounds and structure-activity relationships, Coord. Chem. Rev., 316 (2016) 36-67.

3. E.Z. Jahromi, A. Divsalar, A.A. Saboury, S. Khaleghizadeh, H. Mansouri-Torshizi, I. Kostova, Palladium complexes: new candidates for anti-cancer drugs, J. Iran Chem. Soc., 13 (2016) 967-989.

4. T. Lazarevic, A. Rilak, Z.D. Bugarcic, Platinum, palladium, gold and ruthenium complexes as anticancer agents: Current clinical uses, cytotoxicity studies and future perspectives, Eur. J. Med. Chem., 142 (2017) 8-31.

5. E.J. Baran, V.T. Yilmaz, Metal complexes of saccharin, Coord. Chem. Rev., 250 (2006) 1980-1999.

6. M. Cavicchioli, A.C. Massabni, E.E. Castellano, L.P.B. Sabeh, C.M. Costa-Neto, Synthesis and X-ray structure of the dinuclear platinum(II) complex with saccharin $\left\{\mathrm{K}\left[\mathrm{Pt}(\mathrm{sac})_{3}\left(\mathrm{H}_{2} \mathrm{O}\right)\right] \cdot \mathrm{H}_{2} \mathrm{O}\right\}_{2}$ : studies on its antiproliferative activity in aqueous solution, Inorg. Chim. Acta, 360 (2007) 3055-3060. 
7. E. Ulukaya, F. Ari, K. Dimas, M. Sarimahmut, E. Guney, N Sakellaridis, V.T. Yilmaz, Cell death-inducing effect of novel palladium(II) and platinum(II) complexes on non-small Cell lung cancer cells in vitro, J. Cancer Res. Clin. Oncol., 137 (2011)1425-1434.

8. E. Ulukaya, F. Ari, K. Dimas, E.I. Ikitimur, E. Guney, V.T. Yilmaz, Anti-cancer activity of a novel palladium(II) complex on human breast cancer cells in vitro and in vivo, Eur. J. Med. Chem., 46 (2011) 4957-4963.

9. E. Guney, V.T. Yilmaz, F. Ari, O. Buyukgungor, E. Ulukaya, Synthesis, characterization, structures and cytotoxic activity of palladium(II) and platinum(II) complexes containing bis(2pyridylmethyl)amine and saccharinate, Polyhedron, 30 (2011) 114-122.

10. F. Ari, N. Aztopal, C. Icsel, V.T. Yilmaz, E. Guney, O. Buyukgungor, E. Ulukaya, Synthesis, structural characterization and cell death-inducing effect of novel palladium(II) and platinum(II) saccharinate complexes with 2-(hydroxymethyl)pyridine and 2-(2-hydroxyethyl)pyridine on cancer cells in vitro, Bioorg. Med. Chem., 21 (2013) 6427-6434

11. S.A. Al-Jibori, G.H. Al-Jibori, L.J. Al-Hayaly, C. Wagner, H. Schmidt, S. Timur, F.B. Barlas, E. Subasi, S. Ghosh, G. Hogarth, Combining anti-cancer drugs with artificial sweeteners: synthesis and anti-cancer activity of saccharinate (sac) and thiosaccharinate (tsac) complexes cis-[Pt(sac) $\left.\left(\mathrm{NH}_{3}\right)_{2}\right]$ and cis-[Pt(tsac) $\left.\left(\mathrm{NH}_{3}\right)_{2}\right]$, J. Inorg. Biochem., 141 (2014) 55-57.

12. V.T. Yilmaz, C. Icsel, O.R. Turgut, M. Aygun, M. Erkisa, M.H. Turkdemir, E. Ulukaya, Synthesis, structures and anticancer potentials of platinum(II) saccharinate complexes of tertiary phosphines with phenyl and cyclohexyl groups targeting mitochondria and DNA, Eur. J. Med. Chem., 155 (2018) 609622.

13. C. Icsel, V.T. Yilmaz, M. Aygun, B. Cevatemre, P. Alper, E. Ulukaya, Palladium(II) and platinum(II) saccharinate complexes with bis(diphenylphosphino)methane /ethane: synthesis. S-phase arrest and ROS-mediated apoptosis in human colon cancer cells, Dalton Trans., 47 (2018) 1139711410.

14. V.T. Yilmaz, C. Icsel, M. Aygun, M. Erkisa, E. Ulukaya, Pd(II) and $\mathrm{Pt}(\mathrm{II})$ saccharinate complexes of bis(diphenylphosphino) propane/butane: Synthesis, structures, antiproliferative activity and mechanism of action, Eur. J. Med. Chem., 158 (2018) 534-547.

15. C. Icsel, V.T. Yilmaz, B. Cevatemre, M. Aygun, E. Ulukaya, Structures and anticancer activity of chlorido platinum(II) saccharinate complexes with mono- and dialkylphenylphosphines, J. Inorg. Biochem., 195 (2019) 39 50.

16. C. Icsel, V.T. Yilmaz, B. Cevatemre, M. Aygun, E. Ulukaya, Cytotoxic platinum(II) complexes derived from saccharinate and phosphine ligands: synthesis, structures, DNA cleavage, and oxidative stress-induced apoptosis, J. Biol. Inorg. Chem. 25 (2020) 75-87.
17. C. Icsel, V.T. Yılmaz, M. Aygün, E. Ulukaya, Trans-Pd/Pt(II) saccharinate complexes with a phosphine ligand: Synthesis, cytotoxicity and structure-activity relationship, Bioorg. Med. Chem. Lett., 30 (2020) 127077.

18. C. Icsel, V.T. Yilmaz, B. Cevatemre, M. Aygun, E. Ulukaya, Cytotoxic platinum(II) complexes derived from saccharinate and phosphine ligands: synthesis, structures, DNA cleavage, and oxidative stress-induced apoptosis, J. Biol. Inorg. Chem., 25 (2020) 75-87.

19. V.T. Yilmaz, C. Icsel, O.R. Turgut, M. Aygun, E. Evren, I. Ozdemir, Synthesis, structures and catalytic activity of $\mathrm{Pd}$ (II) saccharinate complexes with monophosphines in direct arylation of five-membered heteroarenes with aryl bromides, Inorg. Chim. Acta, 500 (2020) 119220

20. H.A. Benesi, J.H. Hildebrand, A spectrophotometric investigation of the interaction of iodine with aromatic hydrocarbons, J. Am. Chem. Soc., 71 (1949) 2703-2707.

21. O. Stern, M. Volmer, Über die abklingzeit der fluoreszenz, Z. Physik., 20 (1919) 183-188.

22. J. Min, X.M. Meng-Xia, Z. Dong, L. Yuan, L. Xiao-Yu, C. Xing, Spectroscopic studies on the interaction of cinnamic acid and its hydroxyl derivatives with human serum albumin, J. Mol. Struct., 692 (2004) 71-80.

23. O. Trott, A.J. Olson, Autodock Vina: Improving the speed and accuracy of docking with a new scoring function, efficient optimization and multithreading, J. Comput. Chem., 31 (2010) 455-461.

24. D. Suh, J.B. Chaires, Criteria for the mode of binding of DNA binding agents, Bioorg. Med. Chem., 3 (1995) 723-728.

25. Q. Jiang, N. Xiao, P. Shi, Y. Zhu, Z. Guo, Design of artificial metallonucleases with oxidative mechanism, Coord. Chem. Rev., 251 (2007) 1951-1972.

26. F. Mancin, P. Scrimin, P. Tecilla, U. Tonellato, Artificial metallonucleases, Chem. Commun., (2005) 2540-2548.

27. N.E. Basken, C.J. Mathias, M.A. Green, Elucidation of the human serum albumin (HSA) binding site for the Cu-PTSM and Cu-ATSM radiopharmaceuticals. J. Pharm. Sci., 98 (2009) 2170-2179.

28. P. Mandal, T. Ganguly, Fluorescence spectroscopic characterization of the interaction of human adult hemoglobin and two isatins, 1-methylisatin and 1-phenylisatin: a comparative study, J. Phys. Chem. B, 113 (2009) 14904-14913.

29. D.C. Carter, J.X. Ho, Structure of serum albumin, Adv. Protein Chem., 45 (1994) 153-203. 